\title{
Memahami Konsep Pembentukan dan Pendidikan Karakter Anak Usia Dini Menurut Agama Islam, Pakar Pendidikan, dan Negara
}

\author{
Nita Yuniarti ${ }^{1}$, Siskandar $^{2}$, Akhmad Shunhaji $^{3}$, Endan Suwandana ${ }^{4}$ \\ 1,2,3 Manajemen Pendidikan Islam Anak Usia Dini - Program Pasca Sarjana Institut PTIQ Jakarta \\ ${ }^{4}$ Badan Pengembangan Sumber Daya Manusia Daerah Provinsi Banten \\ mrs.nitayuniarti@gmail.com
}

\begin{abstract}
Abstrak
Pendidikan karakter, khususnya pada anak usia dini, merupakan bagian terpenting dalam pembangunan karakter generasi muda bangsa. Namun diskursus mengenai definisi pendidikan karakter menurut negara dan menurut Agama Islam terkadang masih menjadi perbincangan akademis. Kajian ini bertujuan untuk menyajikan berbagai pandangan tentang pembentukan dan pendidikan karakter menurut perspektif agama Islam, pakar pendidikan, dan ketentuan yang berlaku di negara Indonesia. Kajian ini menggunakan metode studi pustaka dengan melakukan konten analisis terhadap permasalahan yang dikaji. Hasil analisis menyimpulkan bahwa seluruh pendapat dari perspektif agama, pendapat para pakar pendidikan, dan ketentuan kebijakan yang diatur negara tidak ada yang bertentangan, bahkan saling menguatkan untuk diimplementasikan dalam mewujudkan masyarakat yang beriman dan sejahtera dengan akhlak yang mulia. Pendidikan karakter dimaknai sebagai pendidikan yang mengembangkan nilai-nilai universal sehingga peserta didik memiliki nilai dan karakter sebagai dirinya, menerapkan nilai-nilai tersebut dalam kehidupan sosial, baik sebagai umat beragama yang religius maupun sebagai warga masyarakat yang nasionalis dan produktif. Penelitian ini memberikan kontribusi ilmiah bagi para pendidik khususnya dalam mendisain dan menerapkan pendidikan karakter di lingkungan pendidikan sejak usia dini dengan menyelaraskan teori dan praktek dari sisi agama, pendapat ahli, dan negara. Karena sifatnya berupa kajian pustaka, kelemahan kajian ini tidak menggali informasi dari responden (pakar) dengan wawancara secara langsung.

Kata Kunci: pengembangan karakter anak; pendidikan moral; perkembangan usia dini
\end{abstract}

\section{Understanding the Concept of Early Childhood Character Formation and Education Based on Religion of Islam, Education Experts, and the State}

\begin{abstract}
Character education, especially in early childhood, is the most important part in building the character of the nation's young generation. However, the discourse on the definition of character education according to Islam and the state sometimes becomes an academic debate. This literature review aims to present various views on the formation and character education according to the perspective of Islam, education experts, and the regulations in Indonesia. This study uses the literature review method by conducting content analysis. The results of the analysis conclude that all opinions either from religious perspective, education experts, and policy provisions regulated by the state are not contradictory, it is mutually reinforcing instead to be implemented in order to realize a faithful and prosperous society with noble characters. Character education is interpreted as education that develops universal values for the students to have values and character as their own character, applies these values in their social lives, both as religious people and as nationalist and productive citizens. This research provides a scientific contribution for educators, especially in designing and implementing character education in the educational environment from an early age by aligning theory and practice from the perspective of religion, expert opinion, and the state. Because this study uses literature review, the weakness of this study is that it does not dig up information from respondents (experts) through direct interviews.
\end{abstract}

Keywords: childhood character development; moral education; early childhood development 


\section{PENDAHULUAN}

Pendidikan karakter di dalam sistem pendidikan nasional memiliki peranan yang sangat penting. Salah satu tujuan utama pendidikan karakter adalah untuk mewujudkan peradaban bangsa yang berkarakter mulia. Tugas negara untuk mewujudkan kehidupan masyarakat dan bangsa yang berkarakter dan bermartabat tentu bukan sesuatu hal yang mudah (Wardhani \& Wahono, 2017). Hal itu terbukti dengan masih tingginya angka kriminalitas di tengah-tengah masyarakat. Bahkan, dewasa ini beberapa jenis kriminalitas juga banyak dilakukan oleh generasi remaja (Diananda, 2019; Setiawan, 2014). Angka kriminalitas pada kalangan generasi muda itu malah menunjukkan peningkatan dari waktu ke waktu (Unayah \& Sabarisman, 2016).

Peningkatan angka kejahatan di tanah air telah dilaporkan oleh banyak literatur. Salah satunya adalah melalui publikasi Badan Pusat Statistik (BPS, 2018), di mana selama periode 2011-2018, jenis kejahatan pencurian terus meningkat dan paling banyak jumlahnya di pedesaan dan kelurahan di seluruh Indonesia. Persentase desa yang mengalami kejadian pencurian meningkat dari sekitar 36 persen (2011) menjadi 45 persen (2018), di antaranya terdapat enam jenis kejahatan yang mengalami peningkatan, yakni pembunuhan, penganiayaan, perkosaan, penipuan, pencurian, penggelapan, pembakaran dengan sengaja, penyalahgunaan pengedaran narkoba dan perjudian. Tingkat kejahatan yang tinggi tersebut secara langsung maupun tidak langsung merupakan sisi lain dari refleksi capaian pendidikan bangsa.

Meningkatnya kasus-kasus kejahatan di atas, menurut Surachmad (2003) menunjukkan bahwa pendidikan kita belum mampu membangun karakter. Pendapat senada juga pernah diungkapkan oleh Muslich (2015), di mana praktik pendidikan di kelas-kelas tidak lebih dari latihan skolastik, seperti mengenal, membandingkan, melatih, dan menghapal, yakni kemampuan kognitif yang sangat sederhana. Demikian juga Ainiyah \& Wibawa (2013) yang menyatakan bahwa proses pembelajaran baru sebatas pada peningkatan ranah kognitif saja.

Permasalahan inilah yang kemudian mendorong dilakukannya beberapa penelitian untuk mencari tahu apakah peningkatan angka kriminalitas itu dikarenakan oleh kegagalan pendidikan karakter (Sumadi, 2018; Wardhani \& Wahono, 2017; Wardani, 2010) dalam sistem pendidikan nasional? atau apakah konsep pendidikan yang dikembangkan oleh negara belum banyak mengakomodasi nilai-nilai agama? Bahkan lebih jauh, apakah konsep pendidikan karakter yang selama ini dikembangkan oleh negara berbeda dengan konsep pendidikan karakter yang diajarkan oleh agama, khususnya Islam? 
Salah satu penelitian yang terkait dengan hal ini pernah dilakukan oleh Pawitasari et al. (2015), di mana penelitian ini mengkritisi konsep pendidikan karakter yang dikembangkan oleh Kementerian Pendidikan dan Kebudataan (Kemdikbud) agar tidak menyimpang dari konsep pendidikan Islam. Penelitian ini menyatakan bahwa kurikulum yang dikembangkan negara jangan sampai menjadi boomerang bagi umat Islam, karena lebih banyak mengadopsi infiltrasi teori dari negara barat. Namun pertanyaannya sekarang, apakah memang konsep pendidikan karakter yang dikembangkan oleh negara Indonesia berbeda dengan konsep pendidikan karakter yang diajarkan oleh Islam?

Kajian literatur ringkas ini bertujuan untuk menjawab pertanyaan di atas dengan menyajikan berbagai pandangan tentang pembentukan dan pendidikan karakter menurut perspektif agama Islam, pakar pendidikan, dan ketentuan di negara Indonesia. Kajian ini diharapkan dapat memberikan manfaat bagi pengetahuan para pendidik khususnya dalam meramu dan menerapkan pendidikan karakter di lingkungan pendidikan sejak usia dini, baik secara teori maupun praktek.

Topik kajian ini tentunya bukan merupakan hal yang baru. Beberapa kajian terdahulu mengenai konsep pendidikan karakter pernah dilakukan di antaranya oleh (Ainiyah \& Wibawa, 2013; Saifullah \& Ainissyifa, 2017; Sajadi, 2019; Setiawan, 2014; Tadjuddin, 2018b; Yuslaini, 2018). Namun demikian, kajian yang membahas pendidikan karakter sekaligus dari tiga perspektif yaitu Agama Islam, hukum negara, dan pakar pendidikan dalam bentuk tulisan ringkas masih sangat terbatas, untuk itulah maka kajian ini dilakukan dengan harapan dapat memberikan kontribusi akademis mengenai pendidikan karakter di tanah air.

\section{METODE PENELITIAN}

Penelitian ini merupakan kajian literatur (library research) dengan pendekatan kualitatif deskriptif. Alasan pemilihan metode ini karena kajian ini bertujuan untuk mengupas dan membandingkan pendapat para ahli, agama dan negara, dari berbagai sumber, sehingga sangat tepat jika menggunakan kajian pustaka. Teknik analisis yang dilakukan adalah dengan a) mengindentifikasi sumber bacaan, b) mensortir sumber bacaan, c) melakukan analisis isi (content analysis), dan d) menarik kesimpulan dari berbagai sumber tersebut mengenai pendidikan karakter, khususnya pada anak usia dini. Studi literatur ini dilakukan selama tiga 
bulan, namun untuk kepentingan publikasi, penulisan naskah masih terus berlanjut sampai mendapat persetujuan dari mitra bestari dan editor jurnal.

Dalam penelitian ini, sumber-sumber materi kajian berasal dari pendapat para ahli pendidikan yang diwakili oleh beberapa tokoh nasionalis religius yaitu Ki Hajar Dewantara (1889 - 1959) dan Ratna Megawangi (1958 - sekarang), tokoh pendidikan Islam yaitu Abdullah Nashih 'Ulwan (1928 - 1987), dan tokoh pendidikan Barat Thomas Lickona (1943 - sekarang). Pemilihan pakar ini dengan mempertimbangkan latar belakang pendidikan yang berbeda, negara yang berbeda, serta periode masa yang berbeda. Adapun sumber rujukan dari negara Indonesia terutama adalah dari Undang-Undang Sistem Pendidikan Nasional No. 20 Tahun 2003 dan peraturan turunannya.

\section{HASIL DAN PEMBAHASAN}

\section{A. Hasil}

\section{Perbandingan Pendidikan Karakter Menurut Agama Islam dan Negara}

\section{Pendidikan Karakter Menurut Agama Islam}

Sebagaimana telah dijelaskan di muka, beberapa kajian termutakhir yang mengangkat masalah pendidikan karakter menurut perspektif Islam pernah dilakukan oleh (Sajadi, 2019; Yuslaini, 2018; Setiawan, 2014; Ainiyah \& Wibawa, 2013). Pendidikan karakter menurut Islam dimulai dari sebelum manusia itu dilahirkan, bahkan sebelum pasangan rumah tangga terjalin. Menurut (Sajadi, 2019), pendidikan karakter Islam berlandaskan pada 'aqidah. Selanjutnya, 'aqidah itulah yang akan mendasari dibentuknya pendidikan karakter di dalam Islam. Di dalam terminologi Islam, pendidikan karakter dikenal dengan sebutan pendidikan akhlak dan menjadi prioritas utama pendidikan. Menurut Mohammad Athiyah al-Abrasyi (Nata, 2015), pendidikan akhlak adalah jiwa dari pendidikan Islam. Mencapai akhlak yang sempurna adalah tujuan sebenarnya dari pendidikan.

Muhaimin (2011) berpandangan bahwa pendidikan yang terkandung dalam Al-Qur'an adalah untuk mengembangkan potensi manusia seoptimal mungkin dan dapat difungsikan sebagai sarana bagi pemecahan masalah hidup dan kehidupan, pengembangan ilmu pengetahuan dan teknologi serta budaya manusia dan pengembangan sikap iman dan takwa kepada Allah SWT. Al-Qur'an telah melakukan proses penting dalam pendidikan manusia sejak diturunkannya wahyu pertama kepada Nabi Muhammad Shallahu Alaihi wa sallam. Ayat 
ini mengajak kepada manusia untuk meraih ilmu pengetahuan melalui pendidikan membaca, yaitu dalam Al-Qur’an surat Al-‘Alaq (96): 1 - 6, yang isinya:

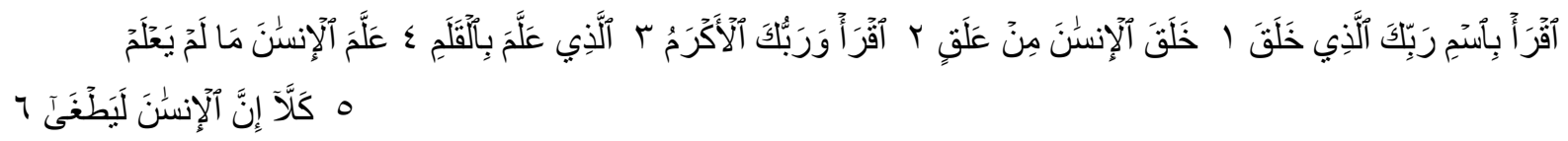

Bacalah dengan (menyebut) nama Tuhanmu Yang menciptakan. Dia telah menciptakan manusia dari segumpal darah. Bacalah, dan Tuhanmulah Yang Maha Pemurah. Yang mengajar (manusia) dengan perantaran kalam. Dia mengajar kepada manusia apa yang tidak diketahuinya. Ketahuilah! Sesungguhnya manusia benar-benar melampaui batas.

Dalam perspektif Islam (Suharto dkk, 2013) karakter unggul dan mulia digambarkan dengan akhlak Nabi Muhammad SAW, manusia termulia, yang termanifestasi dalam semua perkataan, perbuatan, dan persetujuannya. Akhlak unggul Nabi antara lain; benar (ash-shidq), cerdas (al-fathanah), amanah (al-amanah), menyampaikan (at-tabligh), komitmen yang sempurna (al-iltizam), berakhlak mulia ('ala khuluqin 'azhiim), dan teladan yang baik (uswatun hasanah). Sesuai dengan yang diisyaratkan dalam Al-Qur'an surat al-Qolam: 68 ayat 4 yang maknanya sebagai berikut:

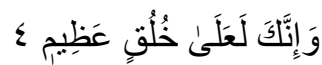

Dan sesungguhnya kamu benar-benar berbudi pekerti yang agung

Dilansir dari Katsir (2018), Ibnu Jarir Ath Thabari (839 - 932) mengatakan bahwa Aisyah Ummul Muminin mengatakan bahwa akhlak Rasulullah shallallahu 'alaihi wa sallam adalah Al-Qur'an. Imam Ahmad pun mengabarkan dari Aisyah bahwa Rasulullah shallallahu 'alaihi wa sallam sama sekali belum pernah memukulkan tangannya kepada seorang pun dari pelayannya, dan belum pernah memukul seorang pun dari istri (beliau), dan belum pernah memukulkan tangannya kepada sesuatu pun kecuali bila dalam berjihad di jalan Allah.

Dalam diri Rosulullah sallallahu 'alaihi wa sallam tergambar karakter yang sempurna, sehingga keagungan dan keluhuran tampak dari perilaku sehari-hari. Perihal watak Rasulullah digambarkan oleh Aisyah Radhiyallahu 'anha bahwa beliau tidak pernah memukul pelayannya sekalipun.artinya beliau begitu menjaga sikapnya.

Dari diskusi di atas, dapat disimpulkan bahwa pendidikan karakter menurut agama Islam adalah pendidikan karakter yang menekankan pada akhlak kepada Tuhan dan nabi-Nya, Akhlak kepada sesama manusia, serta akhlak kepada alam sekitar. Inilah konsep pendidikan karakter yang paripurna, yaitu pendidikan karakter yang mengembangkan tiga dimensi akhlak 
yaitu kepada akhlak Tuhan sebagai sang pencipta, akhlak kepada sesama manusia tempat manusia berkomunikasi dan bersosialisasi, dan kepada alam semesta dimana manusia hidup dan berkembang.

\section{Pendidikan Karakter Menurut Negara}

Menurut Anwas (2010), pendidikan karakter di dalam negara Indonesia adalah sebuah proses dalam membudayakan dan memberdayakan nilai-nilai luhur di lingkungan sekolah, keluarga dan masyarakat. Nilai luhur ini tentu bersumber dari teori psikologi pendidikan, nilai sosial budaya, ajaran agama, dasar negara Pancasila dan Undang Undang Dasar 1945, serta Undang-Undang No. 20 Tahun 2003 tentang pendidikan nasional, serta praktik nyata dalam kehidupan sehari-hari.

Proses pembudayaan dan pemberdayaan ini tentu memerlukan dukungan dari semua pihak yang terkait serta dukungan beberapa perangkat hukum yang diperlukan. Oleh karenanya, terbitlah Instruksi Presiden Nomor 12 Tahun 2016 Tentang Gerakan Nasional Revolusi Mental, Peraturan Presiden Nomor 87 Tahun 2017 Tentang Penguatan Pendidikan Karakter, dan Peraturan Menteri Pendidikan dan Kebudayaan Nomor 20 tahun 2018 tentang Penguatan pendidikan Karakter Pada Satuan Pendidikan Formal.

Dalam melaksanakan pendidikan karakter di Indonesia, ada beberapa landasan yang perlu dijadikan rujukan supaya pendidikan karakter yang diajarkan tidak menyimpang dari jati bangsa Indonesia. Di antara landasan tersebut menurut Zubaedi (2013) adalah:

(a) Landasan Agama. Agama merupakan landasan utama dan merupakan sumber kebaikan. Indonesia merupakan negara yang mayoritas masyarakatnya beragama. Mereka mengakui bahwa kebajikan dan kebaikan bersumber dari agama. Oleh karenanya pendidikan karakter harus dilandaskan berdasarkan nilai-nilai ajaran agama, khususnya pada lembaga pendidikan anak usia dini, dan tidak boleh bertentangan dengan agama.

(b) Landasan Pancasila. Pancasila, dengan kelima silanya, merupakan dasar negara Indonesia yang menjadi acuan dalam pelaksanaan negara dan pemerintahan. Pancasila adalah kepribadian dan pandangan hidup seluruh bangsa Indonesia yang disetujui oleh wakil-wakil rakyat menjelang dan sesudah proklamasi kemerdekaan. Nilai-nilai yang terkandung di dalam Pancasila menjadi acuan dalam kehidupan politik, hukum, ekonomi, kemasyarakatan, budaya, dan seni. 
(c) Landasan Budaya. Indonesia adalah negara yang kaya akan keberagaman budaya. Dengan demikian, nilai budaya tentu harus dijadikan rujukan dalam konsep pergaulan dan komunikasi antar anggota masyarakat. Budaya yang ada di Indonesia harus menjadi sumber nilai dalam pendidikan karakter di Indonesia.

Berdasarkan grand design yang dikembangkan Kemendiknas 2010, secara psikologis dan sosial kultural pembentukan karakter dalam diri individu merupakan fungsi dari seluruh potensi individu manusia (kogntif, afektif, konatif atau psikomotorik) dalam ranah interaksi sosial kultural (keluarga, sekolah, masyarakat) dan berlangsung sepanjang hayat. Konfigurasi karakter dalam konteks totalitas proses psikologis dan sosial-kultural tersebut dapat dikelompokkan dalam olah hati (spiritual and emotional development), olah pikir (intellectual development), olahraga dan kinestetik (physic and kinesthetic development), dan olah rasa dan karsa (affective and creatinity development), sebagaimana dijelaskan oleh Zubaedi (2013).

Dengan mempelajari tujuan pendidikan nasional yang dirumuskan dalam UndangUndang Sistem Pendidikan Nasional, maka dapat disimpulkan beberapa hal mengenai pendidikan karakter (Zuriah, 2007) di antaranya adalah: a) bertujuan untuk menanamkan seperangkat nilai yang menjadi ciri manusia seutuhnya, menyelaraskan nilai agama dan kebudayaan, b) erat kaitannya dengan public culture, demi meningkatkan keimanan dan ketakwaan, c) diselenggarakan sebagai keteladanan, membangun kemauan dan mengembangkan kreativitas, d) diperkaya dengan berbagai ilmu pengetahuan dan masalah sosial agar meluaskan penalaran dan pengembangan kognitif, d) digunakan dengan pendekatan field psychology, pendekatan pemecahan masalah, dan metode inkuiri, e) dikembangkan dengan kegiatan membaca, menulis, menghitung, bagi setiap anggota masyarakat, dan f) perlu peran pendukung dari keluarga, sekolah, masyarakat, serta media lainnya.

Proses pendidikan karakter tidak mudah dibangun pada setiap individu maupun kelompok, karena dalam prosesnya banyak faktor yang menentukan keberhasilan dalam membentuk manusia berkarakter. Proses dalam pendidikan karakter dilakukan melalui beberapa tahapan, baik secara makro maupun mikro. Dalam skala makro pendidikan karakter mencakup seluruh konteks perencanaan dan implementasi pengembangan nilai atau karakter yang melibatkan seluruh stakeholders pendidikan. Adapun dalam skala mikro, pendidikan karakter berlangsung dalam konteks satuan pendidikan atau sekolah secara paripurna. Dengan demikian, menurut Mulyasa (2012)' peserta didik diharapkan mampu menginternalisasikan dan 
mempersonalisasikan nilai-nilai karakter dan akhlak mulia, berdasarkan Pancasila dan UUD 1945 (Rachmah, 2013), sehingga mampu menciptakan manusia yang berbudi pekerti luhur.

\section{Perbandingan Pendidikan Karakter Menurut Para Pakar Pendidikan \\ Pendidikan Karakter Menurut Abdullah Nashih 'Ulwan}

Nashih 'Ulwan adalah tokoh yang dipilih dalam kajian ini mewakili dunia timur, khususnya Islam. Pemikiran Nashih 'Ulwan tentang pendidikan karakter pada anak dimulai sejak sang calon orang tua menikah dengan memilih pasangan yang tepat untuk memasuki jenjang pernikahan. Setelah anak lahir ke dunia, maka ada tujuh hal yang wajib dilakukan dalam melakukan pendidikan kepada anak, yaitu ('Ulwan, 2018):

(a) Tanggung Jawab Pendidikan Iman. Keimanan dipupuk dengan membuka kehidupan anak dengan kalimat tauhid La ilaha illallah, mengajarkannya masalah halal dan haram setelah ia berakal, memerintahkan untuk beribadah saat umurnya tujuh tahun, mendidiknya untuk cinta kepada nabi, keluarganya, dan cinta membaca Al-Qur'an.

(b) Tanggung Jawab Pendidikan Moral. Agar anak berakhlak lurus, maka diajarkan berkepribadian islami di antaranya menghindari taqlid buta (ikut-ikutan), mencegah agar tidak terlalu berlebihan dalam kesenangan, melarang melakukan hal tercela, melarang bergaya seperti lawan jenis, melarang membuka aurat, tabarruj, ikhtilat, dan melihat halhal yang diharamkan.

(c) Tanggung Jawab Pendidikan Fisik. Tanggung jawab pendidikan fisik dimaksudkan supaya anak bisa tumbuh dan dewasa dengan memiliki fisik yang kuat, sehat dan bersemangat dengan menjaga kesehatan dan makan minum yang dihalalkan.

(d) Tanggung Jawab Pendidikan Akal. Orang tua wajib membentuk pola pikir anak terhadap segala sesuatu yang bermanfaat, baik berupa ilmu syar'i, kebudayaan, ilmu modern, kesadaran berfikir dan beradab.

(e) Tanggung Jawab Pendidikan Kejiwaan. Mendidik anak sejak usia dini agar menjadi manusia yang berani dan jujur, mandiri. Sasaran pendidikan ini adalah membentuk anak, menyempurnakan serta menyeimbangkan kepribadiannya, sehingga ketika memasuki usia taklif ia telah mampu melaksanakan kewajibannya dengan penuh makna.

(f) Tanggung Jawab Pendidikan Sosial. Maksud pendidikan sosial yang yang ditumbuhkan kepada anak adalah dengan mengajari anak sejak dini untuk berpegang pada etika sosial yang utama dan dasar. 
(g) Tanggung Jawab Pendidikan Seks. Pendidikan Seks adalah memberikan pengajaran, pengertian yang jelas kepada anak ketika dia telah mengerti hal yang berkaitan dengan seks dengan menanamkan apa yang telah diajarkan oleh Islam.

Selanjutnya, Nashih 'Ulwan juga mencanangkan lima pondasi dalam metode mendidik anak ('Ulwan, 2018), yaitu:

(a) Mendidik dengan Keteladanan. Hal ini merupakan cara yang paling efektif karena pendidik adalah panutannya, di mana disadari atau tidak, anak akan meniru tingkah laku pendidiknya.

(b) Mendidik dengan Kebiasaan. Anak dilahirkan sudah diciptakan dalam keadaan bertauhid, agama yang murni dan iman yang lurus. Untuk menjaga fitrah anak agar tetap lurus hal yang berdasarkan pembiasaan, pendiktean, dan pendisipinan.

(c) Mendidik dengan Nasihat. Islam adalah agama nasihat. Al-Qur'an menggunakan manhaj ini untuk berbicara pada setiap jiwa. Dengan nasihat akan menumbuhkan kesadaran pada anak tentang prinsi-prinsip Islam.

(d) Mendidik dengan Perhatian atau Pengawasan. Mendidik dengan cara ini merupakan asas yang kuat untuk membentuk manusia yang seimbang, dengan mengikuti perkembangan anak dan mengawasinya dalam pembentukan aqidah, akhlak, mental serta jiwa sosialnya.

(e) Mendidik dengan Hukuman. Pemberian hukuman jika anak melakukan kelalaian, akan mencegah anak dari karakter yang tercela. Anak akan jera untuk selalu mengikuti syahwatnya. Tanpa itu anak akan terus ingin berbuat sesuatu yang keji.

\section{Pendidikan Karakter Menurut Ki Hajar Dewantara}

Ki Hajar Dewantara dipilih pada kajian ini untuk merepresentasikan tokoh pendidikan yang berhaluan nasionalis religius. Selain mengeyam pendidikan di tanah air, beliau juga memiliki pendidikan di negeri Belanda. Menurut Dewantara (Wiryopranoto dkk, 2017), pendidikan adalah proses pembetukan karakter manusia agar menjadi sebenar-benar manusia. Dewantara telah memikirkan pendidikan karakter sejak lama. Menurutnya perbuatan mengasah kecerdasan budi adalah suatu kebaikan, karena dapat membangun budi pekerti yang baik dan kokoh, dan mampu mewujudkan kepribadian serta karakter. Penanaman karakter sejak awal menjadikan manusia senantiasa dapat mengalahkan nafsu dan tabiat-tabiatnya yang asli pemarah, kikir, keras, dan lain-lain.

Dewantara mengutarakan bahwa pendidikan adalah suatu tuntunan dalam hidup tumbuhnya anak-anak. Anak itu sebagai makhluk, sebagai manusia, sebagai benda hidup 
tumbuh menurut fitrahnya sendiri. Kaum pendidik hanya dapat memunculkan apa yang masih terpendam dalam jiwa anak-anak. Menuntun anak-anak agar memiliki hidup yang berfaedah (Wiryopranoto dkk, 2017).

Pendidikan karakter menurut Dewantara terbentuk melalui Tri Pusat Pendidikan yang memiliki andil besar dalam proses tumbuh kembangnya seorang anak. Tripusat Pendidikan mengakui adanya pusat-pusat pendidikan yaitu pendidikan di lingkungan keluarga, pendidikan di lingkungan perguruan, dan pendidikan di lingkungan kemasyarakatan atau alam pemuda.

Menurut Wiryopranoto dkk (2017), cara Dewantara mendidik disebutnya sebagai "peralatan pendidikan", yaitu memberi contoh (voorbeelt), pembiasaan (pakulinan, gewoontevorming), pengajaran (wulang-wuruk), laku (zelfbeheersching), dan pengalaman lahir dan batin (nglakoni, ngrasa). Cara pendidikan tersebut sangat tepat digunakan dalam membangun karakter anak bangsa. Cara pendidikan itu juga hampir seluruhnya sesuai dengan metode yang diajarkan dalam agama Islam sebagaimana yang dijelaskan oleh Nashih 'Ulwan sebelumnya. Hal ini menunjukkan bahwa sebagai tokoh nasionalis religius yang pernah mendapatkan pendidikan di Eropa, konsep pendidikan karakter yang diungkapkan oleh Dewantara, sangat bersesuai dengan konsep pendidikan karakter menurut Islam.

\section{Pendidikan Karakter Menurut Ratna Megawangi}

Ratna Megawangi adalah tokoh kedua yang mewakili pakar pendidikan nasionalis religius. Megawangi (2016) menuturkan bahwa kepercayaan kita pada tiga modal dasar yang dimiliki Indonesia yaitu wilayah yang luas, sumber daya alam yang melimpah, dan jumlah penduduk yang besar akan membawa kita menjadi bangsa sejahtera, ternyata tidak terbukti. Bahkan, negara kecil seperti Hongkong dan Singapura sekarang merupakan negara maju yang dipandang dunia tidak memiliki tiga sumber daya di atas. Para pakar sepakat bahwa kunci suksesnya sebuah negara adalah terletak dalam budaya yang kondusif untuk bisa maju, yang dicerminkan pada karakter dan perilaku masyarakatnya yang disebut sebagai "modal sosial".

Menurut Megawangi ada sembilan pilar karakter dasar (Q-Anees \& Soenandar, 2008), meliputi: a) cinta kepada Allah dan semesta beserta isinya, b) tanggung jawab, disiplin dan mandiri, c) Jujur, d) hormat dan Santun, e) kasih sayang, peduli dan kerjasama, f) percaya diri, kreatif, kerja keras, pantang menyerah, g) keadilan dan kepemimpinan, h) baik dan rendah hati, i) toleransi, cinta damai dan persatuan. Kesembilan pilar tersebut harus dikembangkan dan saling terkait dengan landasan pendidikan karakter di Indonesia. Menurut Megawangi (2016) 
kesembilan karakter tersebut didasarkan pada orientasi pendidikan karakter untuk mengembangkan general life skill anak dari jenjang pra sekolah sampai sekolah menengah.

Adapun aspek general life skill yang berkaitan dengan sembilan pilar karakter adalah:

(a) Kesadaran Diri (self-awareness), termasuk keimanan sebagai makhluk Tuhan Yang Maha Esa, pengembangan karakter: cinta kebenaran, tanggung jawab dan disiplin, saling menghargai, dan membantu, serta belajar memelihara lingkungan.

(b) Kesadaran akan potensi diri, termasuk belajar menolong diri sendiri dan belajar menumbuhkan kepercayaan diri.

(c) Kecakapan sosial (social skill), termasuk empati dan kerja sama.

Menurut Megawangi (2016), ada tiga kebutuhan dasar anak yang harus dipenuhi, yaitu maternal bonding (kelekatan psikologis dengan ibunya) yang merupakan dasar penting dalam pembentukan karakter anak karena aspek ini berperan dalam pembentukan dasar kepercayaan kepada orang lain (trust); rasa aman, yaitu kebutuhan anak akan lingkungan yang stabil dan aman; dan stimulasi fisik dan mental. Seorang ibu yang sangat perhatian (yang diukur dari seringnya ibu melihat mata anaknya, mengelus, menggendong, dan berbicara kepada anaknya yang berusia usia di bawah enam bulan) akan mempengaruhi sikap bayinya sehingga menjadi anak yang gembira, antusias mengeksplorasi lingkungannya, dan menjadikan anak yang kreatif.

\section{Pendidikan Karakter Menurut Thomas Lickona}

Tokoh pendidikan karakter yang mewakili budaya Barat yang diambil dalam penelitian ini adalah Thomas Lickona. Lickona (2017) memaparkan bahwa isi dari karakter yang baik adalah kebaikan, yaitu seperti kejujuran, keberanian, keadilan, dan kasih sayang adalah disposisi untuk berperilaku secara bermoral. Karakter merupakan objektifitas yang baik atas kualitas manusia. Kebaikan memenuhi kriteria tertentu, kebaikan menentukan apa artinya jadi manusia, kebaikan meningkatkan kesejahteraan dan kebahagiaan seorang individu. Dia terinspirasi dari budaya Yunani tentang sepuluh esensi kebajikan yang berpengaruh dalam pembentukan karakter, yaitu kebijaksanaan, keadilan, keberanian, pengendalian diri, cinta, sikap positif, bekerja keras, integritas, rasa syukur, dan kerendahan hati.

Lickona mengemukakan bahwa karakter berkaitan dengan pengetahuan moral (moral knowing), perasaan moral (moral feeling) dan perilaku moral (moral behavior). Melalui tiga komponen ini maka karakter yang baik harus didukung oleh pengetahuan tentang kebaikan, keinginan untuk berbuat baik dan melakukan perbuatan kebaikan (Zubaedi, 2013). 


\section{B. Pembahasan}

Setelah menelaah konsep-konsep pendidikan karakter dari peraturan peraturan dan kebijakan di negara Indonesia dan konsep menurut Islam, maka kedua konsep tersebut sejatinya sejalan dan tidak bertentangan. Konsep pendidikan karakter yang diatur negara sesuai dengan konsep agama Islam yang membangun manusia pada tiga dimensi, yaitu akhlak kepada Tuhan (sila pertama Pancasila), akhlak kepada manusia (sila kedua Pancasila), dan akhlak kepada alam semesta (sila kedua dan kelima Pancasila). Menurut (Sajadi, 2019), konsep pendidikan karakter atau akhlak bersifat universal dan fitriah, yaitu konsep pendidikan yang menjadikan manusia selain berakhlak terpuji juga menjadi warga negara yang baik.

Konsep pendidikan karakter menurut agama Islam sudah paripurna, karena konsep itu berdasarkan pada wahyu ilahi. Begitu pula konsep pendidikan karakter menurut negara juga sudah lengkap karena berdasarkan pada kesepakatan para founding fathers negara yang juga memiliki nilai-nilai religius. Menurut Haq (2011), walaupun bukan sesuatu yang sakral, namun Pancasila adalah hasil rumusan kesepakatan pendiri bangsa yang nilai-nilainya diambil dari kandungan agama-agama, termasuk Islam khususnya.

Konsep pendidikan karakter menurut negara dan agama Islam memang tidak dapat dipertentangkan, karena kedua hal tersebut bertujuan untuk mewujudkan manusia yang berakhlak mulia. Hal itu sesuai dengan definisi karakter itu sendiri menurut salah satu teori pendidikan yang dinyatakan sebagai:

"One's character is an indelible mark of consistency and predictability. It denotes enduring dispositional tendencies in behavior. It points to something deeply rooted in personality, to its organizing principle that integrates behavior, attitudes, and values.” (Lapsley \& Narvaez, 2007).

Artinya, selama kedua konsep tersebut bertujuan untuk menciptakan manusia yang memiliki personality yang baik yang mengintegrasikan tingkah laku, sikap, dan nilai-nilai di dalam dirinya, maka kedua konsep tersebut memiliki tujuan pokok yang sama. Tiga landasan yang merupakan sumber rujukan utama bagi pelaksanaan pendidikan karakter di Indonesia, yaitu agama, Pancasila, dan budaya bangsa merupakan sumber acuan yang komperehensif. Tiga sumber itu sudah sangat cukup digunakan dalam membangun karakter bangsa.

Begitu pun dari hasil analisis pendapat para pakar pendidikan, secara garis besar konsep pendidikan karakter yang dikemukakan oleh para tokoh pendidikan baik yang berhaluan Islam, nasionalis religius, maupun budaya Barat menunjukkan banyak titik kesamaan. Semua 
pendapat tokoh itu menyepakati bahwa konsep pendidikan karakter menekankan pada konsep ketuhanan, pendidikan moral, menghargai hak asasi manusia, serta cinta kepada alam sekitar.

Kesimpulan dari kajian ini tentu bukan merupakan sesuatu hal yang baru, karena telah banyak tokoh dari generasi-generasi sebelumnya yang juga menyimpulkan tentang adanya kesamaan konsep pendidikan Islam dan negara. Selain Ki Hajar Dewantara dan Ratna Megawangi, beberapa tokoh nasional dan tokoh peneliti sebelumnya pernah menyimpulkan bahwa pendidikan Islam bersesuaian dengan pendidikan yang dikembangkan di negara Indonesia antara lain Prof. Buya Hamka, Wahid Hasyim, Prof. Arif Rahman Hakim, Prof. Mohammad Mahfud Mahmodi (Mahfud MD), dan Prof. Hamka Haq. Kesamaan-kesamaan dalam konsep pendidikan karakter inilah yang dapat digunakan oleh para pendidik muda dalam mendisain strategi pembelajaran pendidikan karakter di tanah air dari sejak usia dini.

Namun demikian, tingginya angka kriminalitas yang terjadi di tanah air, akhirnya masih menyisakan pertanyaan di benak masyarakat tentang apa yang harus diperbaiki dari pendidikan karakter. Kegagalan dalam menekan angka kejahatan itu mendorong para akademisi untuk kembali mengkritisi konsep pendidikan karakter yang dikembangkan negara. Sebagian tokoh masih mempertentangkan konsepnya, sebagian lain hanya mengkiritisi proses internalisasinya yang dirasakan kurang efektif dalam menciptakan generasi muda yang berakhlak mulia.

Salah satu kajian yang masih mempertentangkan konsep pendidikan karakter menurut agama dan negara adalah Pawitasari et al. (2015), di mana konsep pendidikan karakter yang dikembangkan oleh Kemendikbud dinilai belum konsisten. Menurutnya, dalam beberapa literatur dijelaskan bahwa acuan pendidikan karakter adalah konsensus nasional yaitu Pancasila, UUD 45, Bhinneka Tunggal Ika, dan komitmen NKRI. Sedangkan pada rujukan yang lain, Kemendibud menjelaskan bahwa dasar acuan nilai pendidikan karakter adalah agama, Pancasila, budaya, dan tujuan pendidikan nasional.

Penelitian lain (Syahrul, 2018) juga menyatakan bahwa konsep pendidikan karakter di Indonesia belum jelas, karena sampai saat ini kita masih dilema dalam menentukan idelologi negara, apakah demokrasi, Pancasila, atau demokrasi Pancasila. Menurutnya, Pancasila dan Demokrasi sangat berbeda dari segi ideologi, karena Pancasila berideologikan ke-Tuhanan, sedangkan demokrasi berideologikan liberal (kebebasan untuk mau percaya Tuhan atau tidak). Sehingga menurutnya, tidak mungkin kita menggabungkan kedua konsep itu ke dalam sebuah konsep lain yang dinamakan demokrasi Pancasila. Ketidakjelasn inilah yang menurutnya akan menyebabkan ketidakjelasan dalam pengembangan pendidikan karakter di tanah air. 
Selain mempertentangkan pada tataran konsep, ada juga akademisi yang mengkritrisi pelaksanaan pendidikan karakter, yang dinilai belum berhasil, termasuk oleh Azhari (2017). Menurut Pawitasari et al. (2015) praktek pendidikan karakter yang dilakukan Kemendikbud bersifat indoktrinatif, di mana nilai-nilai karakter yang diajarkan di sekolah bersifat nisbi (relatif) yang bersumber pada standar masing-masing guru yang wajib diterima oleh peserta didik yang terkadang tanpa melalui proses diskusi dan dialog, walaupun, masih menurut Pawitasari et al. (2015), fakta ini tidak diakui oleh Kemendikbud sendiri. Selain itu menurutnya, pendidikan karakter juga cenderung rentan terhadap infiltrasi konsep pendidikan yang berasal dari budaya asing daripada nilai agama atau budaya yang dianut oleh bangsa Indonesia sendiri.

Lahirnya kritik terhadap implementasi pendidikan karakter dewasa ini menyebabkan sebagian masyarakat meragukan pola pendidikan karekter pada satuan pendidikan umum dan memilih pendidikan karakter berbasiskan Islam, misalnya melalui pendidikan pesantren (Oktari \& Kosasih, 2019; Saifullah \& Ainissyifa, 2017; Nofiaturrahmah et al., 2014; dan Fuad, 2013). Pesantren dianggap lebih mampu menyelesaikan degradasi karakter bangsa dibandingkan dengan pola pendidikan karakter pada satuan pendidikan umum.

Jika ditelaah secara seksama, maka lahirnya paradigma di atas sebenarnya bukan karena konsep pendidikan karakter menurut ketentuan negaranya yang keliru, namun karena implementasinya yang masih rancu, belum jelas, atau tidak makimal. Hal itu mungkin juga terjadi karena sekolahlah yang pada akhirnya mendefiniskan lebih lanjut bagaimana implementasi pendidikan karakter itu (Ningsih, 2015). Bahkan, bisa jadi implementasi itu diserahkan kepada pemahaman masing-masing guru (Pawitasari et al., 2015). Menurut Mukhibat (2012), mungkin inilah saatnya kita harus melakukan reinventing terhadap nilai-nilai dari ketiga landasan (agama, Pancasila, dan budaya) dalam pengembangan pendidikan karakter di tanah air.

Hasil penelitian ini, walaupun tidak menghasilkan kesimpulan atau teori baru, namun diharapkan dapat memberikan memberikan dukungan pada kajian-kajian sebelumnya dan tambahan referensi ilmiah khususnya bagi para pendidik milenial yang hidup pada generasi saat ini, dimana konsep Islam dan negara sedang hangat kembali didiskusikan dalam forum nasional. Menghangatnya kembali wacana konsep Islam dan nasionalis dalam beberapa tahun terakhir diungkapkan di antaranya oleh Fernandes (2019), Nasrudin (2019), Haboddin (2012), dan Maarif (2010). Menghangatnya kembali konsep Islam dan negara di tataran politik, tentu 
diharapkan tidak berimbas pada diskursus mengenai hal serupa mengenai konsep pendidikan menurut Islam dan negara.

Dari berbagai literatur yang dijelaskan di muka, hasil kajian ini jelas menyimpulkan bahwa secara konsep, sejatinya pendidikan karakter di negara Indonesia sudah jelas, yaitu dibangun atas dasar nilai agama, Pancasila dan budaya. Bahkan Pancasila itu sendiri, sebagai fundamen negara, telah dibangun di atas nilai-nilai luhur agama yang diundangkan oleh para pendiri bangsa yang juga religius. Banyaknya kesamaan mengenai teori-teori pendidikan karakter baik menurut Islam, negara dan tokoh-tokoh pendidikan, menunjukkan bahwa konsepkonsep itu sangat solutif dan komplementer.

Namun demikian, bukan berarti di antara teori dan konsep pendidikan karakter tersebut sama sekali tidak memiliki perbedaan. Tentu secara fislosofi, karakter pendidikan Islam memiliki perbedaan pada tataran nilai ketuhanan ('aqidah). Setiap karakter pada ketentuan negara hanya dapat bernilai benar dan salah pada hukum positif di dunia. Namun dalam pendidikan karakter menurut agama Islam, nilai itu juga memiliki konsekuensi pahala dan dosa di akhirat.

Perbedaan lainnya misalnya pada praktik pemenuhan sebuah karakter. Sebagai contoh, karakter berbuat sopan santun, baik menurut konsep Islam, negara, maupun budaya barat, merupakan karakter universal (fitriah) yang harus dilakukan oleh manusia ketika berinteraksi dengan sesamanya. Namun pelaksanaan sopan tentu tersebut tentu memiliki pengertian yang berbeda dari sudut pandang agama Islam, budaya Indonesia, maupun budaya Barat. Dalam berpakaian misalnya, di antara suku-suku yang ada di Indonesia, pakaian sopan dan perilaku sopan dimaknai berbeda-beda. Demikian juga berpakaian sopan menurut definsi Islam.

Secara umum, nilai-nilai karakter dan moral itu bersifat universal kebenarannya, namun bagaimana implementasinya diatur oleh norma agama dan budaya yang berlaku di sebuah wilayah tertentu. Bahkan menurut Nurwahyuni (2019), implementasi nilai karakter itu juga bisa berbeda untuk setiap generasi. Sebuah perilaku sopan, pada generasi X, bisa jadi akan berubah maknanya pada generasi, Y, Z atau generasi lainnya, sehingga implementasi pendidikan karakter bisa jadi berbeda untuk setiap generasi. 


\section{SIMPULAN DAN SARAN}

Kajian literatur ini bertujuan untuk mengkaji pendidikan karakter dari sudut pandang agama Islam, negara Indonesia, serta menurut beberapa pendapat tokoh pendidikan dengan menggunakan metode content analysis. Meskipun tidak ada kesimpulan yang baru dari penelitian ini, namun demikian penelitian ini dapat memberikan kontribusi dan tambahan referensi ilmiah yang menyegarkan, khususnya bagi para pendidik milenial yang hidup pada generasi teknologi informasi saat ini, dimana konsep Islam dan negara sedang hangat kembali didiskusikan dalam forum wacana nasional. Kajian ini menyimpulkan bahwa konsep pendidikan karakter baik yang diajarkan oleh agama Islam maupun yang dikembangkan oleh negara Indonesia memiliki banyak kesamaan serta memiliki arah tujuan yang sama. Begitu pula konsep pendidikan karakter menurut para tokoh pendidikan baik yang berhaluan Islam, nasionalis religius, maupun barat secara garus besar memiliki konsep, tahapan, dan tujuan yang sama yaitu membangun manusia yang beretika dan memili karakter yang kuat. Konsep-konsep pendidikan yang dikembangkan itu tidak saling bertentangan, bahkan saling menguatkan.

\section{UCAPAN TERIMAKASIH}

Para penulis dengan rendah hati mengucapkan terimakasih yang tak terhingga kepada Program Pasca Sarjana PTIQ serta semua pihak yang telah membantu penulisan karya ilmiah ini. Ucapan terimakasih juga disampaikan kepada para mitra bestari dan editor Jurnal Al Athfal UIN Raden Intan, Lampung.

\section{DAFTAR PUSTAKA}

'Ulwan, A. N. (2018). Pendidikan Anak Dalam Islam (Penerjemah: Arif Rahman Hakim dari Tarbiyyatul Aulad fil Islam). Insan Kamil, Solo, 906p.

Ainiyah, N., \& Wibawa, N. H. H. P. (2013). Pendidikan Karakter Melalui Pendidikan Agama Islam. Al-Ulum, 13(Nomor 1), 25-38.

Anwas, O. M. (2010). Televisi Mendidik Karakter Bangsa: Harapan dan Tantangan. Jurnal Pendidikan Dan Kebudayaan, 16(9), 256. https://doi.org/10.24832/jpnk.v16i9.517

Azhari, J. F. (2017). Kritik Terhadap Implementasi Pendidikan Karakter. Jurnal Subulana, 1(1), 72-80. https://doi.org/10.47731/subulana.v1i1.7

BPS. (2018). Statistik Kriminal 2018. Badan Pusat Statistik, Jakarta, 186p.

Daniel K. Lapsley, \& Narvaez, D. (2007). Character Education: Handbook of Child Psychology (pp. 248-289).

Diananda, A. (2019). Psikologi Remaja Dan Permasalahannya. Journal ISTIGHNA, 1(1), 116- 
133. https://doi.org/10.33853/istighna.v1i1.20

Fernandes, A. (2019). Politik Identitas dalam Pemilu 2019 : Proyeksi dan Efektivitas. Centre For Strategic And International Studies, 1, 1-10.

Haboddin, M. (2012). Menguatnya Politik Identitas Di Ranah Lokal. Journal of Government and Politics, 3(1), 109-126. https://doi.org/10.18196/jgp.2012.0007

Haq, H. (2011). Pancasila 1 Juni dan Syariat Islam. RM Books, Jakarta, 237p. https://doi.org/10.31219/osf.io/5bc26

Katsir, I. (2018). Tafsir Ibnu Katsir Jilid VIII. Pustaka Imam Syafi'i, Bogor, 215p.

Lickona, T. (2017). Character Matters: Persoalan Karakter, Bagaimana Membantu Anak Mengembangkan Penilaian yang Baik, Integritas dan Kebbajikan Penting Lainnya (Penerjemah: Juma Abdu Wamaungo dan Jean Antunes Rudolf Zien dari Characters Matters: How to Help Our Children Deve. Bumi Aksara, Jakarta 376p.

Maarif, A. S. (2010). Politik Identitas dan Masa Depan Pluralisme Indonesia. In Politik Identitas dan Masa Depan Pluralisme Indonesia. Yayasan Abad Demokrasi, Jakarta, $135 \mathrm{p}$.

Megawangi, R. (2016). Pendidikan Karakter: Solusi yang Tepat untuk Membangun Bangsa. Indonesian Heritage Foundation, Depok, 223p.

Muhaimin. (2011). Pemikiran dan Aktualisasi Pengembangan Pendidikan Islam. Rajawali Press, Jakarta, 341p.

Mukhibat, M. (2012). Reinventing nilai-nilai Islam, budaya, dan Pancasila dalam pengembangan pendidikan karakter. Jurnal Pendidikan Islam, 1(2), 247-265. https://doi.org/10.14421/jpi.2012.12.247-265

Mulyasa, H. E. (2012). Manajemen Pendidikan Karakter. Bumi Aksara, Jakarta, 281p.

Muslich, M. (2015). Pendidikan Karakter: Menjawab Tantangan Krisis Multidimensional. Bumi Aksara, Jakarta, 240p.

Nasrudin, J. (2019). Politik Identitas dan Representasi Politik. 1, 34-47. https://doi.org/10.1017/CBO9781107415324.004

Nata, A. H. (2015). Akhlak Tasawuf dan Karakter Mulia. Raja Grafindo Persada, Jakarta 357p.

Ningsih, T. (2015). Implementasi Pendidikan Karakter. In STAIN Press, Purwokerto. https://doi.org/10.32678/qathruna.v7i1.3030

Nofiaturrahmah, F., Program, M., Uin, D., \& Kalijaga, S. (2014). 118230-ID-metodependidikan-karakter-di-pesantren. XI(1), 201-216.

Nurwahyuni, A. (2019). Literature Review: Perbedaan Pendidikan Karakter yang Diterapkan pada Generasi X, Y dan Z. Psikologi Pendidikan, April, 66-75.

Oktari, D. P., \& Kosasih, A. (2019). Pendidikan Karakter Religius dan Mandiri di Pesantren. Jurnal Pendidikan Ilmu Sosial, 28(1), 42. https://doi.org/10.17509/jpis.v28i1.14985

Pawitasari, E., Mujahidin, E., \& Fattah, N. (2015). Pendidikan Karakter Bangsa dalam Perspektif Islam (Studi Kritis Terhadap Konsep Pendidikan Karakter Kementerian Pendidikan \& Kebudayaan). Ta'dibuna: Jurnal Pendidikan Islam, 4(1), 1. https://doi.org/10.32832/tadibuna.v4i1.573

Q-Anees, B., \& Soenandar, R. K. (2008). Pendidikan Karakter Berbasis Al-Qur'an (Issue May). Simbiosa Rekatama Media, Bandung, 164p.

Rachmah, H. (2013). Nilai-Nilai Dalam Pendidikan Karakter Bangsa Yang. E-Jurnal Widya Non-Eksakta, 1(1), 7-14.

Saifullah, I., \& Ainissyifa, H. (2017). Memberdayakan Eksistensi Pesantren. Jurnal Pendidikan Universitas Garut, Vol. 11; N, 124-131.

Sajadi, D. (2019). Pendidikan Karakter Dalam Perspektif Islam. Tahdzib Al-Akhlaq: Jurnal 
Pendidikan Islam, 2(2), 16-34. https://doi.org/10.34005/tahdzib.v2i2.510

Setiawan, A. (2014). Prinsip Pendidikan Karakter Dalam Islam. Jurnal Penelitian Pendidikan Islam, 14(1), 1-12.

Suharto, T., Assagaf, J., \& Islam, S. (2013). Membendung Arus Paham Keagamaan Islam Radikal: Analisis Ideologi atas Materi Kurikulum dalam buku Muslim Integral. Cipta Media Aksara, Yogyakarta, 86p.

Sumadi, E. (2018). Anomali pendidikan karakter. Tarbawi : Jurnal Pendidikan Islam, 15(2). https://doi.org/10.34001/tarbawi.v15i2.846

Surachmad, W. (2003). Mengurai Benang Kusut Pendidikan. Pustaka Pelajar, Jakarta 210p.

Syahrul. (2018). "Kritik Ideologi Pendidikan Karakter dalam Masyarakat Demokrasi di Indonesia." Seminar Nasional Pendidikan Dan Kewarganegaraan IV, 58-67.

Tadjuddin, N. (2018a). Pendidikan Moral Anak Usia Dini dalam Pandangan Psikologi, Pedagogik, dan Agama. Al-Athfaal: Jurnal Ilmiah Pendidikan Anak Usia Dini, 1(1), 100116.

Tadjuddin, N. (2018b). Pendidikan Moral Anak Usia Dini Dalam Pandangan Psikologi, Pedagogik, dan Agama. Al-Athfaal: Jurnal Ilmiah Pendidikan Anak Usia Dini, 1(1), 100 116. https://doi.org/10.24042/ajipaud.v1i1.3386

Unayah, N., \& Sabarisman, M. (2016). Fenomena Kenakalan Remaja Dan Kriminalitas. Sosio Informa, 1(2), 121-140. https://doi.org/10.33007/inf.v1i2.142

Wardani, K. (2010). Peran Guru Dalam Pendidikan Karakter Menurut Konsep Pendidikan Ki Hadjar Dewantara. November, 8-10.

Wardhani, N. W., \& Wahono, M. (2017). Keteladanan Guru Sebagai Penguat Proses Pendidikan Karakter. Untirta Civic Education Journal, 2(1), 49-60. https://doi.org/10.30870/ucej.v2i1.2801

Wiryopranoto, S., M. S. Herlina, N., Marihandono, D., Tangkilisan B, Y., \& Nasional, T. P. K. (2017). Ki Hajar Dewantara: Pemikiran dan Perjuangannya. Museum Kebangkitan Nasional Direktorat Jenderal Kebudayaan Kementerian Pendidikan dan Kebudayaan, Jakarta, 208p.

Yuslaini. (2018). Pendidikan Karakter di Indonesia: Dalam Konteks Pendidikan Islam. In Program Pascasarjana Universitas Islam Negeri Raden Intan Lampung. https://doi.org/10.24090/insania.v16i3.1595

Zubaedi. (2013). Desain Pendidikan Karakter: Konsepsi dan Aplikasinya dalam Lembaga Pendidikan. Kencana Prenada Media Group, Jakarta, 408p.

Zuriah, N. (2007). Pendidikan moral \& budi pekerti dalam perspektif perubahan: menggagas platform pendidikan budi pekerti secara kontektual dan futuristik. Budi Aksara, Jakarta, $268 \mathrm{p}$. 